\title{
Comparison of Early Results Between Single and Quadruple Injection of Corticosteroid-local Anesthetic in Patients with Subacromial Impingement
}

\author{
Subakromial Sıkışma Hastalarında Tekli Kortikosteroid-lokal Anestetik Enjeksiyonu ile \\ Dörtlü Enjeksiyonun Erken Dönem Sonuçlarının Karşılaștııılması
}

(1) Afşar Timuçin Özkut

İstanbul Medeniyet University, Göztepe Training and Research Hospital, Clinic of Orthopedics and Traumatology, İstanbul, Turkey

\begin{abstract}
Introduction: Subacromial impingement syndrome (SAS) is a painful condition of the shoulder that affects daily activities. The objective of this study was to compare the results of single and quadruple injection (with addition of three other possible trigger points) in patients with SAS.

Methods: Sixty-eight patients with the diagnosis of SAS were randomized into two groups. The first group received a single posterior subacromial injection of $1 \mathrm{~mL} 3 \mathrm{mg}$ Betamethasone (BM) $+9 \mathrm{~mL} 5 \mathrm{mg}$ 0.5\% Bupivacaine (BC). The second group received three extra injections in addition to the posterior subacromial injection; $1 \mathrm{~mL} \mathrm{BM}+9 \mathrm{~mL} \mathrm{BC}$ around suprascapular nerve, $1 \mathrm{~mL} \mathrm{BM}+4 \mathrm{~mL} \mathrm{BC}$ into the glenohumeral joint and $1 \mathrm{~mL} \mathrm{BM}+4 \mathrm{~mL} B C$ around the bicipital groove. Visual analog scale (VAS) scores, American Shoulder and Elbow Society (ASES) scores and range of motion of the patients were recorded just before the injection and at $3^{\text {rd }}, 12^{\text {th }}$ and $24^{\text {th }}$ weeks. Independent samples t-test was used to compare the results of the two groups statistically.

Results: Range of motion and ASES scores were found to be higher in the quadruple injection group at all follow-up intervals $(p<0.05)$. VAS scores were statistically better at the third and twelfth week for the quadruple injection group, however the difference between the two groups was statistically insignificant at the sixth month $(p=0.42)$.

Conclusion: Quadruple injection resulted in increased range of motion and better functional scores at follow-up intervals up to six months in patients with subacromial impingement.

Keywords: Quadruple injection, subacromial impingement, conservative
\end{abstract}

öz

Amaç: Subakromial sıkışma sendromu (SSS), omuz ağrısı ile seyreden ve günlük aktiviteleri etkileyen klinik bir tablodur. Bu çalışmanın amacı, SSS olan hastalarda tek enjeksiyonla dörtlü enjeksiyonun (muhtemel 3 tane tetik noktasının eklenerek) sonuçlarının karșılaștırılmasıdır.

Yöntemler: SSS tanısı konan 68 hasta randomize olarak iki gruba ayrılmıştır. illk gruba posteriordan tek bir $1 \mathrm{~mL} 3$ mg Bethamethasone (BM) $+9 \mathrm{~mL} 5 \mathrm{mg} \% 0,5$ Bupivacaine (BC) enjeksiyonu yapılırken, ikinci gruba 4'lü enjeksiyon yapılmıştır: Posterior enjeksiyona ek olarak, supraskapular sinir komșuluğuna $1 \mathrm{~mL} \mathrm{BM}+9 \mathrm{~mL} \mathrm{BC}$, glenohumeral ekleme $1 \mathrm{~mL} \mathrm{BM}+4 \mathrm{~mL} \mathrm{BC}$, bisipital oluk etrafına $1 \mathrm{~mL} \mathrm{BM}+4 \mathrm{~mL}$ BC. Enjeksiyon öncesi ve 3., 12. ve 24. haftadaki VAS skorları, hareket açıklıkları ve ASES skorlamaları kaydedilmiștir. İstatiksel hesaplamalarda, independent t-test kullanılmıștır.

Bulgular: Öne fleksiyon dışındaki tüm hareket açıklıkları ve ASES skorları, dörtlü enjeksiyon grubunda tüm kontrol aralıklarında daha yüksek bulunmuștur $(\mathbf{p}<0.05)$. Altıncı ayda ikinci gruptaki hastalar öne fleksiyon açısından daha memnun iken istatistiksel fark gözlenmemiş̦tir $(p=0.36)$. VAS skorları üçüncü ve on ikinci haftada ikinci grupta daha iyiyken altıncı ayda gruplar arasında anlamlı fark saptanmamıștır $(p=0.33)$.

Sonuç: Dörtlü enjeksiyon subakromial sıkıșma hastalarında altıncı aya kadar olan kontrol aralıklarında, hareket açıklığının artmasını ve fonksiyonal sonuçların daha iyi olmasını sağlamıștır.

Anahtar Kelimeler: Dörtlü enjeksiyon, subakromial sıkışma, konservatif
Address for Correspondence/Yazıșma Adresi: Afşar Timuçin Özkut MD, İstanbul Medeniyet University, Göztepe Training and Research Hospital, Clinic of Orthopedics and Traumatology, Istanbul, Turkey

Phone: +90 5326141478 E-mail: afsarozkut@superonline.com ORCID ID: orcid.org/0000-0003-0624-9600

Cite this article as/Atıf: Özkut AT. Comparison of Early Results Between Single and Quadruple Injection of Corticosteroid-local Anesthetic in Patients with Subacromial Impingement. İstanbul Med J 2019; 20(4): 312-5.
Received/Geliș Tarihi: 05.12.2018 Accepted/Kabul Tarihi: 19.03.2019

(c) Copyright 2019 by the Istanbul Training and Research Hospital/Istanbul Medical Journal published by Galenos Publishing House.

(C) Telif Hakkı 2019 Istanbul Ĕgitim ve Araștırma Hastanesi/Istanbul Tıp Dergisi, Galenos Yayınevi tarafından basılmıștır. 


\section{Introduction}

Subacromial impingement syndrome (SAS) is a wide spectrum of diseases that range from tendinitis to partial or full-thickness rotator cuff tears (1). This common disorder affects daily activities, especially during overhead activities or sleep. The concept of subacromial impingement was first described by Neer (2). The initial management of SAS includes rest or activity modification and shoulder exercises $(3,4)$. Local injections and physiotherapy may also aid in healing of the patients (3,5-8). Although the pharmacologic mechanism of action is not similar, both corticosteroids and local anesthetics produce similar effects with regard to pain and subsequent improvement in strength and upper limb function (9). Combination of corticosteroids and local anesthetics is widely used in orthopedics and general practice in a variety of conditions including SAS. In routine practice, a single injection of corticosteroids and local anesthetics is performed into the subacromial space via posterior or anteromedial route for SAS. There are some studies reporting that the posterior route is more accurate for subacromial injections where as the results were shown to be comparable for either route in another study (10-12). There is sufficient evidence that proves subacromial injection will yield good results since the process of subacromial impingement involves subacromial bursitis and supraspinatus tendinitis.

The aim of this study was to compare the results of a single posterior subacromial injection and quadruple injection (around suprascapular nerve, into glenohumeral joint space and around biceps tendon in addition to the classical subacromial injection). The hypothesis was that the injection of four trigger points could yield better results since it involved the possible areas that could help pain relief.

\section{Methods}

Sixty-eight patients who were admitted to the orthopedics and traumatology clinic with the diagnosis of subacromial impingement between 2017 and 2018 were included in the study. The inclusion criteria were as follows: a) between ages 30 and 70 years, b) the presence of painful arc of motion, c) the presence of impingement and/ or Hawkins sign, and d) the absence of pathologies on plain radiographs besides osteopenia (like osteoarthritis or mesoacromion). The exclusion criteria were as follows: a) the presence of loss of passive motion more than $25 \%$ in at least two directions (forward flexion, internal rotation, external rotation and abduction) compared to the other shoulder, b) the presence of rotator cuff tear in magnetic resonance imaging (MRI) and/or presence of a positive Jobe supraspinatus test during physical examination, c) previous shoulder surgery on the affected side, and d) the presence of systemic diseases that may be related to shoulder disorders, including diabetes mellitus or thyroid disorders. Informed consent was obtained from all participants included in the study. The ethics committee approval for this study was obtained from istanbul Medeniyet University, Göztepe Training and Research (decision no: 2018/0256, date: 18.07 .2018 ). The patients were divided into two groups by simple randomization using $n, n+1$ principle. The first group received a single posterior subacromial injection of $1 \mathrm{~mL} 3 \mathrm{mg}$ Betamethasone $(\mathrm{BM})+9 \mathrm{~mL} 5 \mathrm{mg}$ 0.5\% Bupivacaine (BC). The subacromial injections were performed $2 \mathrm{~cm}$ distal and $2 \mathrm{~cm}$ medial to the posterolateral edge of the acromion. The second group received four injections: $1 \mathrm{~mL} \mathrm{BM}$ $+9 \mathrm{~mL} \mathrm{BC}$ around suprascapular nerve, $1 \mathrm{~mL} \mathrm{BM}+4 \mathrm{~mL} B C$ into the glenohumeral joint and $1 \mathrm{~mL} \mathrm{BM}+4 \mathrm{~mL} \mathrm{BC}$ around the bicipital groove in addition to the posterior subacromial injection. The suprascapular nerve injection was performed according to the indirect technique described by Dangoisse (13) and the entry point was $2 \mathrm{~cm}$ cephalad to the middle of the spine of the scapula. The glenohumeral injection was performed $1 \mathrm{~cm}$ lateral to coracoid process which can easily be palpated. The long head of biceps can easily be palpated while flexing the elbow. The bicipital injection was performed just next to the tendon after feeling the rubbery consistency of the tendon. As the injections were performed, physiotherapy was started the following day and was administered to all patients for 12 weeks. Visual analog scale (VAS) scores, range of motion (measured with a goniometer) and [(American Shoulder and Elbow Society (ASES)] scores of the patients were recorded immediately before injection. The same parameters were recorded at $3^{\text {rd }}, 12^{\text {th }}$ and $24^{\text {th }}$ weeks.

Table 1. Comparison of visual analogue scale, American shoulder and elbow society scores and forward flexion, abduction, internal rotation, external rotation between two groups during follow-up intervals

\begin{tabular}{|c|c|c|c|c|c|c|c|}
\hline Time Point & Group & $\begin{array}{l}\text { VAS scores } \\
\text { (Mean } \pm \text { SD) }\end{array}$ & $\begin{array}{l}\text { ASES scores (Mean } \\
\pm \text { SD) }\end{array}$ & FF (Mean \pm SD) & ABD (Mean \pm SD) & IR (Mean \pm SD) & ER $($ Mean \pm SD $)$ \\
\hline \multirow{2}{*}{ Baseline* } & Group I & $7.2 \pm 0.81$ & $44.4 \pm 2.27$ & $119.4 \pm 5.52$ & $88.13 \pm 4.23$ & $44.1 \pm 3.52$ & $68.2 \pm 3.31$ \\
\hline & Group II & $6.69 \pm 0.86$ & $47.5 \pm 3.09$ & $118.34 \pm 3.82$ & $95.09 \pm 4.04$ & $46.16 \pm 1.55$ & $65.09 \pm 2.63$ \\
\hline \multirow{2}{*}{$3^{\text {rd }}$ Week $^{* *}$} & Group I & $6.67 \pm 0.61$ & $51.77 \pm 2.37$ & $137.3 \pm 4.38$ & $107.8 \pm 4.98$ & $51.4 \pm 3.46$ & $71.03 \pm 3.99$ \\
\hline & Group II & $5.69 \pm 0.86$ & $58.28 \pm 2.5$ & $139.44 \pm 4.1$ & $125.5 \pm 2.44$ & $54.78 \pm 1.56$ & $73.47 \pm 3.44$ \\
\hline \multirow{2}{*}{$3^{\text {rd }}$ Month $* * *$} & Group I & $4.3 \pm 0.65$ & $59.93 \pm 2.43$ & $153.17 \pm 3.42$ & $110.8 \pm 4.77$ & $52.5 \pm 3.39$ & $73.5 \pm 4.03$ \\
\hline & Group II & $3.19 \pm 0.64$ & $67.03 \pm 2.78$ & $153.38 \pm 4.65$ & $125.81 \pm 2.56$ & $57.5 \pm 1.05$ & $79.56 \pm 1.29$ \\
\hline \multirow{2}{*}{$6^{\text {th }}$ Month $* * * *$} & Group I & $2 \pm 0.53$ & $72.53 \pm 2.32$ & $158.1 \pm 3.03$ & $116.17 \pm 5.19$ & $54.3 \pm 3.05$ & $75.43 \pm 3.56$ \\
\hline & Group II & $1.88 \pm 0.66$ & $83.28 \pm 3.38$ & $155.53 \pm 4.38$ & $189.19 \pm 2.21$ & $61.5 \pm 2.42$ & $81.22 \pm 1.13$ \\
\hline$p^{+}$ & - & $\mathrm{p}<0.001$ & $p<0.001$ & $\mathrm{p}<0.001$ & $p<0.001$ & $\mathrm{p}<0.001$ & $p<0.001$ \\
\hline \multicolumn{8}{|c|}{$\begin{array}{l}\text { *Baseline: } p=0.02 ; p<0.001 ; p=0.39 ; p<0.001 ; p<0.01 ; p<0.001 \text { (independent t-tests for baseline scores), ** } 3^{\text {rd }} \text { week: } p<0.001 ; p<0.001 ; p=0.05 ; p<0.001 ; p<0.001 ; p=0.01 \\
\text { (independent } t \text {-tests for } 3^{\text {rd }} \text { week scores), *** } 3^{\text {rd }} \text { month: } p<0.001 ; p<0.001 ; p=0.84 ; p<0.001 ; p<0.001 ; p<0.001 \text { (independent } t \text {-tests for } 3^{\text {rd }} \text { month } \text { scores), } * * * * 6^{\text {th }} \text { month: } p=0.42 \text {; } \\
p<0.001 ; p=0.01 ; p<0.001 ; p<0.001 ; p<0.001 \text { (independent t-tests for } 6^{\text {th }} \text { month scores). }\end{array}$} \\
\hline \multicolumn{8}{|c|}{$\begin{array}{l}\text { VAS: visual analogue scale, ASES: American shoulder and elbow society, FF: forward flexion, ABD: abduction, IR: internal rotation, ER: external rotation, SD: standard deviation, Group I: } \\
\text { experimental group, Group II: control group, }{ }^{+} \text {: Results of one-way ANOVA with repeated measures }\end{array}$} \\
\hline
\end{tabular}




\section{Statistical Analysis}

SPSS version 24.0 (IBM Corp., Armonk, NY, USA) was used for analysis. Mean and standard deviation was reported for each measurement period and each group. Kurtosis and skewness were calculated for normality, and Independent t-test was used to determine differences between groups. One-way ANOVA with repeated measures was performed to define overall effect of measurements at different time points. $\mathrm{P}<0.05$ was considered significant.

\section{Results}

Four patients in the experimental group and two patients in the control group were lost during follow up. The experimental group consisted of 30 patients (11 men, 19 women; mean age: $53.9 \pm 6.6$ years) and the control group consisted of 32 patients ( 9 men, 23 women; mean age: $55.4 \pm 5.2$ years).

For all scores, time has a significant effect on each group as a result of repeated ANOVA measures ( $p<0.001$ for all scores and groups). Independent samples t-test was performed for each time point between each group to indicate which differences were significant between the groups. At baseline, $3^{\text {rd }}$ week and $3^{\text {rd }}$ month time points, the results were statistically significantly better for controls regarding all scores except for forward flexion. All scores were significantly better for controls at $6^{\text {th }}$ month compared to Table 1 experimental group.

\section{Discussion}

The diagnosis of subacromial impingement is usually simple and can be made after several clinical tests. The most reliable diagnostic tests are Hawkins sign and the presence of a painful arc. Conservative treatment should be the initial choice of treatment. Local injection and shoulder exercise therapy should be specific and of low intensity and high frequency (8). The prognostic factors related to conservative treatment along the natural course of subacromial impingement were investigated in a study, and younger age, lower body mass index, higher functional capacity, shorter symptomatic period, reversible changes on MRI, and higher Constant and ASES scores at initial evaluation were reported as good prognostic factors (14). Increased thoracic flexion and a posture with head ahead of trunk, posterior capsule tightness and less passive internal rotation were shown to be related to symptoms when asymptomatic population and subacromial impingement patients were compared (15). Physical therapy may include interventions to increase thoracic extension. One hundred and fifty-seven British Elbow and Shoulder Society member surgeons were asked to complete a questionnaire, and the responses revealed that $97 \%$ of surgeons performed subacromial injection, $87 \%$ repeated the injection if the previous injection was performed by a general practitioner and $94 \%$ recommended physical therapy (40\% for three months) (5).

Corticosteroids are used for their anti-inflammatory and direct analgesic effects. They reduce proinflammatory mediators and have effect on the cells involved in inflammatory responses (16). Other possible mechanisms include local hyperemia, reflex muscle relaxation and enhancing local tissue metabolism (17). Corticosteroid injections may lead to complications such as skin atrophy and discoloration, septic arthritis, as well as deleterious effects on intraarticular cartilage or tendon degeneration and even spontaneous tendon ruptures (18). The onset of action of corticosteroids takes place within 24-48 hours, and its effect enhances for approximately 2-3 weeks (19). Local anesthetics such as lidocaine act by membrane stabilization with a preferential block to small fibers that carry pain and autonomic impulses (20). Some studies suggest that the combination of local anesthetics with corticosteroids is effective, however, some authors state that the results of injection of local anesthetic alone and combination with corticosteroid are comparable $(7,21)$. A prospective, randomized controlled double-blind study involved a lidocaine injection group of 19 patients which was compared with a control group of 20 patients who received lidocaine + triamcinolone injection. During a follow up period of six months, forward flexion and external rotation were significantly increased in the control group (increase forward flexion: $24{ }^{\circ} \mathrm{C}$ vs $11{ }^{\circ} \mathrm{C}$ external rotation: $10^{\circ} \mathrm{C}$ vs $5^{\circ} \mathrm{C}$, respectively) (7). There are also studies against the efficacy of corticosteroids. In another study involving 58 patients with a 6-month follow-up period, xylocaine and xylocaine + betamethasone injection yielded comparable results for all follow-up intervals (21). A meta-analysis of 11 studies and 726 patients reported that corticosteroid injections had no significant effect at three-month follow up (22). In clinical practice, physicians often use a combination of corticosteroid suspension with local anesthetics for local intra-articular injections. The optimal dosage, concentration and volume in the subacromial space are still controversial (9). There are several studies on the combinations of corticosteroid suspension with either high-volume $(23,24)$ or lowvolume (25). A study involving two groups of 26 patients reported that 3 cc lidocaine +1 cc triamcinolone and 9 cc lidocaine +1 cc triamcinolone yielded comparable results during a follow-up of 8 weeks (9).

Neer's three-stage classification is commonly used in the literature to evaluate patients with subacromial impingement (26). In our study, only patients with Neer type 1 and 2 impingement that did not have a partial or full tear of the rotator cuff were included to provide homogenous sample groups. The three additional trigger points that are highly possible to play a major role in pain were targeted for local injection. The first one is around the suprascapular nerve. Infiltration of suprascapular nerve by injection contributes tremendously in pain relief, so the suprascapular nerve block is commonly used for the treatment of chronic painful shoulder, especially in adhesive capsulitis (27). The relationship between subacromial impingement, posterior capsule tightness and loss of internal rotation has been clearly defined (27). The second injection into the glenohumeral joint space through the rotator interval is likely to yield better range of motion, especially in terms of internal rotation, and it may also help alleviate symptoms related to synovitis in the glenohumeral joint. Our results have shown that patients with restricted internal rotation had better range of motion after the fourth injection. The third point is near the long head of biceps, since it has been already shown that the biceps tendon is commonly involved in subacromial impingement and that it plays a leading role in shoulder pain $(28,29)$. Pain relief in the short term is crucial for patients with shoulder pain. Shoulder disorders frequently lead to depression secondary to chronic pain, which interferes with daily activities, and sleep quality is almost always negatively affected. A recent study has shown that shoulder pain affecting the patients for more than three months resulted in depression, anxiety and sleep disorders (30). 


\section{Conclusion}

The results in this study were better with the fourth injection during six months follow-up in terms of range of motion (excluding forward flexion) and ASES scores. VAS scores improved significantly until the third month, as the scores were indifferent at six months. The range of motion was increased, especially in terms of internal-external rotation and abduction with multiple injection technique. The main target in the treatment of subacromial impingement is strengthening the rotator cuff muscles. Reaching this target is easier when the patient is painless with a greater range of motion. Further studies may be necessary for the long-term results of multiple injections.

Ethics Committee Approval: The ethics committee approval for this study was obtained from İstanbul Medeniyet University, Göztepe Training and Research (decision no: 2018/0256, date: 18.07.2018).

Informed Consent: Informed consent was obtained from all participants included in the study.

Peer-review: Externally peer-reviewed.

Financial Disclosure: The authors declared that this study received no financial support.

\section{References}

1. Koester MC, George MS, Kuhn JE. Shoulder impingement syndrome. Am J Med 2005; 118: 452-5.

2. Neer CS 2nd. Anterior acromioplasty for the chronic impingement syndrome in the shoulder: a preliminary report. J Bone Joint Surg Am 1972; 54: 41-50.

3. Steuri R, Sattelmayer M, Elsig S, Kolly C, Tal A, Taeymans J et al. Effectiveness of conservative interventions including exercise, manual therapy and medical management in adults with shoulder impingement: a systematic review and meta-analysis of RCTs. Br J Sports Med. 2017; 51: 1340-7.

4. Björnsson Hallgren HC, Lars E, Adolfsson LE, Johansson K, Öberg B, Peterson A et al. Specific exercises for subacromial pain Good results maintained for 5 years. Acta Orthopaedica 2017; 88: 600-5.

5. Bryceland JK, Drury C, Tait GR. Current UK practices in the management of subacromial impingement. Shoulder Elbow. 2015; 7: 164-7.

6. Lin KM, Wang D, Dines JS. Injection therapies for rotator cuff disease. Orthop Clin North Am. 2018; 49: 231-9.

7. Blair B, Rokito AS, Cuomo F, Jarolem K, Zuckerman JD. Efficacy of injections of corticosteroids for subacromial impingement syndrome. J Bone Joint Surg Am. 1996; 78: 1685-9.

8. Diercks R, Bron C, Dorrestijn O, Meskers C, Naber R, de Ruiter T et al. Guideline for diagnosis and treatment of subacromial pain syndrome A multidisciplinary review by the Dutch Orthopaedic Association Acta Orthopaedica 2014; 85: $314-22$.

9. Sumanont S, Arirachakaran A, Apiwatanakul P, Boonrod A, Kanchanatawan W, Kongtharvonskul J. Short-term outcomes of subacromial injection of combined corticosteroid with low-volume compared to high volume local anesthetic for rotator cuff impingement syndrome: a randomised controlled non-inferiority trial. Eur J Orthop Surg Traumatol 2018; 28: 1079-87.

10. Ramappa A, Walley KC, Herder LM, Iyer S, Zurakowski D, Hall A, et al. Comparison of anterior and posterior cortico-steroid injections for pain relief and functional improvement in shoulder impingement syndrome. Am J Orthop (Belle Mead NJ) 2017; 46: 257-62.

11. Henkus HE, Cobben LP, Coerkamp EG, Nelissen RG, van Arkel ER. The accuracy of subacromial injections: a prospective randomized magnetic resonance imaging study. Arthroscopy 2006; 22: 277-82.
12. Esenyel CZ, Esenyel M, Yeșiltepe R, Ayanoğlu S, Bülbül M, Sirvanci M, et al. The correlation between the accuracy of steroid injections and subsequent shoulder pain and function in subacromial impingement syndrome. Acta Orthop Traumatol Turc 2003; 37: 41-5.

13. Dangoisse MJ, Wilson DJ, Glynn CJ. MRI and clinical study of an easy and safe technique of suprascapular nerve blockade. Acta Anaesthesiol Belg 1994; 45: 49-54.

14. Ertan S, Ayhan E, Güven MF, Kesmezacar H, Akgün K, Babacan M.Mediumterm natural history of subacromial impingement syndrome.J Shoulder Elbow Surg 2015; 24: 1512-8.

15. Land $\mathrm{H}$, Gordon S, Watt K. Clinical assesment of subacromial impingement - Which factors differ from the asymptomatic population? Musculoskelet Sci Pract 2017; 27: 49-56.

16. Caldwell JR. Intra-articular corticosteroids. Guide to selection and indications for use. Drugs 1996; 52: 507-14.

17. Ekeberg OM, Bautz-Holter E, Tveita EK, Juel NG, Kvalheim S, Brox JI. Subacromial ultrasound guided or systemic steroid injection for rotator cuff disease: randomised double blind study. BMJ 2009; 338: 312.

18. Gaujoux-Viala C, Dougados M, Gossec L. Efficacy and safety of steroid injections for shoulder and elbow tendonitis: a meta-analysis of randomised controlled trials. Ann Rheum Dis 2009; 68: 1843-9.

19. Foye PM, Sullivan WJ, Panagos A, Zuhosky JP, Sable AW, Irwin RW. Industrial medicine and acute musculoskeletal rehabilitation. 6. Upper- and lower-limb injections for acute musculoskeletal injuries and injured workers. Arch Phys Med Rehabil 2007; 88(3 Suppl 1): 29-33.

20. Hsieh LF, Kuo YC, Lee CC, Liu YF, Liu YC, Huang V. Comparison Between Corticosteroid and Lidocaine Injection in the Treatment of Tennis Elbow: A Randomized, Double-Blinded, Controlled Trial. Am J Phys Med Rehabil 2018; 97: 83-9.

21. Alvarez CM, Litchfield R, Jackowski D, Griffin S, Kirkley A. A prospective, double-blind, randomized clinical trial comparing subacromial injection of betamethasone and xylocaine to xylocaine alone in chronic rotator cuff tendinosis. Am J Sports Med 2005; 33: 255-62.

22. Mohamadi A, Chan JJ, Claessen FM, Ring D, Chen NC. Corticostero idinjections give small and transient pain relief in rotator cuff tendinosis: A Meta-analysis. Clin Orthop Relat Res 2017; 475: 232-43.

23. Carroll MB, Motley SA, Wohlford S, Ramsey BC. Rilonacept in the treatment of subacromial bursitis: a randomized, non-inferiority, unblinded study versus triamcinolone acetonide. Joint Bone Spine 2015; 82: 446-50.

24. Hong JY, Yoon SH, Moon DJ, Kwack KS, Joen B, Lee HY. Comparison of high- and low-dose corticosteroid in subacromial injection for periarticular shoulder disorder: a randomized, triple-blind, placebo-controlled trial. Arch Phys Med Rehabil 2011; 92: 1951-60.

25. Naredo E, Cabero F, Beneyto P, Cruz A, Mondejar B, Uson J, et al. A randomized comparative study of short term response to blind injection versus sonographic-guided injection of local corticosteroids in patients with painful shoulder. J Rheumatol 2004; 31: 308-14.

26. Neer CS 2nd. Impingement lesions. Clin Orthop Relat Res 1983: 70-7.

27. Tyler TF, Nicholas SJ, Roy T, Gleim GW. Quantification of posterior capsule tightness and motion loss in patients with shoulder impingement. Am J Sports Med 2000; 28: 668-73.

28. Patton WC, McCluskey GM 3rd. Biceps tendinitis and subluxation. Clin Sports Med 2001; 20: 505-29.

29. Murthi AM, Vosburgh CL, Neviaser TJ. The incidence of pathologic changes of the long head of the biceps tendon. J Shoulder Elbow Surg 2000; 9: 382-5.

30. Cho CH, Jung SW, Park JY, Song KS, Yu KI. Is shoulder pain for three months or longer correlated with depression, anxiety, and sleep disturbance? J Shoulder Elbow Surg 2013; 22: 222-8. 